\title{
Decline of maternal blood lead concentrations in Glasgow
}

\author{
Michael R Moore, Stuart J Robertson, W Harper Gilmour, Gordon D Murray, \\ Andrew Britton, Robert A Low, Graham C M Watt
}

\section{National Research \\ Centre for \\ Environmental \\ Toxicology, University \\ of Queensland, \\ Australia \\ M R Moore}

West of Scotland Water Authority, Glasgow

S J Robertson

A Britton

Department of Public Health, University of Glasgow, Glasgow W Harper Gilmour

Medical Statistics Unit, University of Edinburgh, Edinburgh G D Murray

\section{Stobhill General Hospital, Glasgow R A Low}

Department of General Practice, University of Glasgow, Glasgow

G C M Watt

Correspondence to: Professor M R Moore, National Research Centre for Environmental Toxicology,

The University of

Queensland, 39 Kessels

Road, Coopers Plains,

Queensland 4108, Australia.

Accepted for publication 24 March 1998
Seventeen years ago we reported ${ }^{1}$ the public health success of reduced lead exposure of mothers in Glasgow, achieved between 1977 and 1980 by increasing the $\mathrm{pH}$ of the water supply from 6.3 to 9.0 with lime to reduce plumbosolvency. A further reduction in plumbosolvency has now been made by addition of orthophosphate to the water supply. We report here on striking changes in maternal blood lead concentrations observed after this second measure to reduce lead exposure from drinking water and a decade of general lead abatement in our society.

\section{Methods}

Blood lead concentrations were observed in a population of mothers living in the same catchment area of Stobhill General Hospital in the north of the city as we reported on previously. ${ }^{1}$ A $50 \%$ random sample of 214 mothers was selected from the 428 who gave birth in Stobhill between October and December 1991. Home visits were made between October 1992 and March 1993 to 76 mothers randomly selected from the 138 responders when samples of maternal blood, daytime tap water, and kettle water were obtained. Sampling procedures and determination of blood lead and water lead concentrations were by methods previously described. ${ }^{2}$ The study was approved by the community and primary care research ethics committee of the Greater Glasgow Health Board.

\section{Results}

The geometric mean blood lead concentration was $3.5 \mu \mathrm{g} / \mathrm{dl}(0.17 \mu \mathrm{mol} / \mathrm{l})$. In $4 \%$ (3 of 76 ) of cases $(95 \%$ CI $1 \%, 11 \%)$ maternal blood lead exceeded $10 \mu \mathrm{g} / \mathrm{dl}(0.48 \mu \mathrm{mol} / \mathrm{l})$ and no mother had a blood lead above $25 \mu \mathrm{g} / \mathrm{dl}(1.21 \mu \mathrm{mol} / \mathrm{l})$. Daytime water lead results ranged from $<2$ to $16 \mu \mathrm{g} / 1(<10-77 \mathrm{nmol} / \mathrm{l})$ with $22 \%$ (17 of 76 ) above $2 \mu \mathrm{g} / \mathrm{l}$. Kettle water lead results ranged from $<2$ to $25 \mu \mathrm{g} / 1(<10-121 \mathrm{nmol} / \mathrm{l})$ with $27 \%$ (20 of 74 ) above $2 \mu \mathrm{g} / 1$.

The median age of mothers was 32, ranging from 21 to 44. All mothers lived in households supplied with low alkalinity water derived from either Loch Katrine (64\%) or Loch Lomond (36\%) to which orthophosphate addition was introduced in 1989 and 1991 respectively.

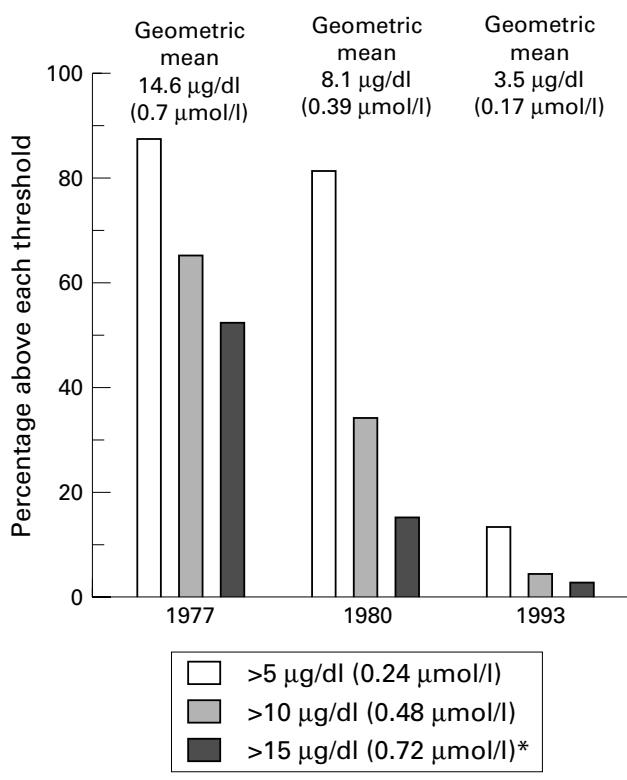

Figure 1 Prevalence of raised blood lead in mothers giving birth at Stobhill Hospital, Glasgow. Studies in 1977, 1980, and 1993. * The threshold for 1977 and 1980 is $14.5 \mu \mathrm{g} / \mathrm{dl}$ $(0.70 \mu \mathrm{mol} / \mathrm{l})$ rather than $15 \mu \mathrm{g} / \mathrm{dl}(0.72 \mu \mathrm{mol} / \mathrm{l})$.

\section{Discussion}

In comparable populations ${ }^{134}$ of mothers, the geometric mean blood lead concentration was $14.6 \mu \mathrm{g} / \mathrm{dl}(0.70 \mu \mathrm{mol} / \mathrm{l})$ in 1977 (236 cases) and $8.1 \mu \mathrm{g} / \mathrm{dl}(0.39 \mu \mathrm{mol} / \mathrm{l})$ in 1980 (475 cases). The prevalence of maternal blood lead above $10 \mu \mathrm{g} / \mathrm{dl}(0.48 \mu \mathrm{mol} / \mathrm{l})$ (fig 1$)$ was $65 \%$ in $1977(95 \%$ CI $59 \%, 71 \%)$ and $34 \%$ in 1980 (95\%CI 30\%, 38\%).

The low drinking water lead concentrations observed in the homes of Stobhill mothers in 1993 reflect the trend in the city as a whole where the estimated ${ }^{2}$ prevalence of lead in daytime samples above the present $50 \mu \mathrm{g} / 1$ (242 nmol/1) European Commission standard was $83 \%$ in $1977,13 \%$ in 1980 , and $2 \%$ in 1993 .

The substantial decline in blood lead concentrations in this susceptible section of the population is encouraging. Reduction in blood lead between 1977 and 1980 was ascribed ${ }^{3}$ to treatment of the water supply alone, as little had been done in that period to abate lead from other sources. Since 1980 there have been diverse moves to reduce environmental lead exposure, including changes in food canning 
technology and introduction of lead free petrol; the much lower blood lead concentrations reported ${ }^{2}$ for given tap water lead exposures in 1993 compared with a decade earlier are consistent with reduced lead exposure from non-water sources. Reduction in blood lead between 1980 and 1993 therefore parallels reduced exposure from both water and nonwater sources of lead.

Although orthophosphate addition to the water supply has further reduced plumbosolvency, and may have reduced the bioavailability ${ }^{5}$ of lead from this source, drinking water remains the main correlate of raised maternal blood lead in Glasgow ${ }^{2}$ where an estimated $50 \%$ of the 290000 households still have some lead pipework between the water main and the kitchen tap. Currently there are no other established water treatment technologies to further reduce water lead concentrations; removal of lead pipework from the homes of pregnant women and their children would therefore need to be encouraged to sustain further reduction in the tap water contribution to maternal blood lead.
We thank mothers who took part in the study and freely provided access to their homes. We also wish to thank Mary Stewart who carried out the home visits, Margaret Slowman who maintained the research office, Steven Davis and colleagues at West of Scotland Water Rutherglen Laboratory for water lead analyses, Dr David Halls and colleagues at Glasgow Royal Infirmary for blood lead analyses, and Dr John Womersley of Greater Glasgow Health Board for help with the sampling frame.

Views expressed in this paper are those of the authors and not necessarily those of their respective organisations.

Funding: this study was part of a project funded by the Scottish Office Health Department, and supported by the Greater Glasgow Health Board and by Strathclyde Regional Council Water Department (from April 1996 West of Scotland Water Authority).

Conflicts of interest: SJR and AB are employed by West of Scotland Water Authority.

1 Moore MR, Goldberg A, Morton Fyfe W, et al. Maternal ead levels after alterations to the water supply. Lancet $1981 ;$ ii, 203-4.

2 Watt GCM, Britton A, Gilmour $\mathrm{H}$, et al. Is lead in tap water still a public health problem? An observational study in Glasgow. BMF 1996;313:979-81.

3 Moore MR, Goldberg A, Meredith PA, et al. Contribution of drinking water to maternal blood lead concentrations. Clin Chim Acta 1979;95:113-22.

4 Moore MR, Richards WN, Sherlock JG. Successful abatement of lead exposure from water supplies in the west of Scotland. Environ Res 1985;38:67-76.

5 Wroath AS, Fawell JK. Bioavailability of metals from drinking water. London: United Kingdom Water Industry Research, 1995:report no.2/95. 